\title{
US and Europe face gap over money for CERN
}

Washington. Officials from CERN, the European Laboratory for Particle Physics in Geneva, Switzerland, have been visiting Washington this week in an attempt to get negotiations moving on US participation in the proposed Large Hadron Collider (LHC) project.

CERN and the United States agreed last month to set up three working groups to proceed with negotiations which, both promised, would be completed this year. But according to one US official, two of the three working groups are unable to start work because of the gulf between the two sides on the size of the US contribution.

Hubert Curien, president of the CERN Council and a former French research minister, Volker Soergel, Germany's delegate to the council, and Chris Llewellyn Smith, director-general of CERN, were due to have a meeting on Monday (26 February) with Charles Curtis, deputy secretary of the US Department of Energy (DoE), and Jack Gibbons, chief scientific adviser to President Bill Clinton.

Although neither side has said publicly how much they feel the United States might contribute, the $\$ 400$ million recommended by the DoE's High Energy Physics Advisory Panel (see Nature 369, 266; 1994) is widely seen as the starting point for the negotiations.

But, as a result of their different accounting methods, $\$ 400$ million means quite different things to each side. Indeed, one US official estimates that it would cost the United States $\$ 600-\$ 800$ million to provide what the Europeans would regard as a $\$ 400$-million contribution.

CERN expects to spend $\$ 2.5$ billion on the construction of the LHC. But that will be in addition to internal spending by CERN and the laboratories of its member countries, whose contribution will come to the project without cost.

To secure the political viability of the project in Europe, CERN would like the United States to contribute as much as possible that can be offset against the $\$ 2.5$ - billion construction cost. A US contribution, for example, that consisted entirely of steel with no intellectual content at all - could be offset to its full value. But a US contribution of software, which might technically be worth more to the project, but which the European laboratories could have written themselves at no cost to CERN, would have no value as an offset.

The width of the gap between the two sides is due to the fact that both would like the United States to make a major contribution not just of hardware but also of expertise. The United States wants an exciting project for its scientists and engineers to work on, and Europe wants as much technical help as possible; but the more expertise the United States provides, the lower the offset value of its contribution.

Llewellyn Smith met US officials in Washington in January (see Nature 379, 197; 1996), but Curien missed the meeting because of weather conditions. Officials say that little progress was made in bridging the fundamental gap, but the two sides did agree that detailed negotiations should be conducted by three working groups dealing with administration, the detectors and the accelerator respectively. Colin Macilwain

\section{HIV vaccine: sell-out or vote of confidence by Genentech?}

Washington. Genentech Inc. of South San Francisco, California, one of the leading US biotechnology companies, after more than a decade of trying to develop an HIV vaccine, has announced that it is setting up a separate company, Genenvax, Inc., to try to bring the vaccine, gp120, to market.

Genentech said last week that it is investing \$2 million to help start the new company, to which it will grant exclusive rights to gp120. Genenvax plans to seek an additional $\$ 18$ million in private financing, in order to launch broad-based clinical trials of the vaccine in the United States and Thailand.

But plans to develop gp120 remain controversial. Some critics are concerned that volunteers for large-scale human trials might risk infection with HIV in the mistaken belief that the vaccine is completely effective. Others suggest that the planned tests in Thailand could be open to the charge that a vaccine rejected for phase- 3 testing by US officials is being dumped in a developing country.

But Don Francis, an early pioneer of AIDS virology, and president of the new company, is optimistic. "Genenvax is an innovative solution to an important issue," says Francis. "[It] allows for singularity of purpose in developing the gp120 vaccine.'

Francis was responsible for Genentech's efforts to develop gp120, which proceeded through phase- 2 testing, but were delayed in 1994 when an advisory panel to the National Institute of Allergy and Infectious Diseases (NIAID) recommended against phase-3 trials (see Nature 369, 593 1994). He disputes the charges made by critics.

"People that call [the proposed Thai tests] a 'dump' are just looking for excuses not to get answers, good or bad, to scientific questions," he says, pointing out that the World Health Organization's Global Programme on AIDS approved efficacy trials in October 1994, soon after NIAID's opposing decision.

Francis also claims that phase-3 testing is now essential for gp120's development. "We are approaching the plateau of our abilities to define potential efficacy in the laboratory," he says. "We've now got to move to empirical real life challenges."

But AIDS activists disagree. "Genentech is cutting its losses," suggests Gregg Gonzalves, policy director with Treatment Action Group, an AIDS support group in New York. "Nobody thinks the gp120 products are worthy of going into phase 3 testing."

Industry observers agreed that Genentech is trying to distance itself from a controversial vaccine. "If you're willing to sell something, you're not desperate to keep it yourself," said David Stone, an analyst with Cowen \& Co., a New York-based investment bank and brokerage firm. But Francis says that Genentech's decision shows its dedication to gp120. By removing the vaccine from competition with other projects, he says, it has created a company "devoted

\section{IMAGE \\ UNAVAILABLE FOR COPYRIGHT REASONS}

Testing grounds: Thailand's red light district could be prime target for Genenvax's HIV vaccine

and focused" on the vaccine.

Genentech has spent more than $\$ 50$ million on gp120 since the mid-1980s. It stockpiled more than 100,000 doses of the vaccine in anticipation of the phase- 3 trials that did not materialize. These supplies, along with adjuvants and pre-clinical and clinical data, will be passed to Genevax.

Genentech will provide $\$ 1$ million in seed capital to Genenvax, and an additional \$1 million after $\$ 18$ million is raised in private funds. When private financing closes, Genentech will retain a 25 per cent equity investment in the company. Francis says he hopes that private sources will in fact contribute between $\$ 30$ million and $\$ 40$ million. Genenvax's chairman is Robert Nowinski, a virologist and biotechnology entrepreneur.

Meredith Wadman 